\title{
Facts that Influence College Students' Reading Motivation
}

\begin{abstract}
By Suhua Huang ${ }^{*} \&$ Marcie Reynolds ${ }^{ \pm}$
This study investigated American college students' reading motivation. A total of 1,437 (533 male and 904 female) college students across interdisciplinary areas voluntarily participated in the study by completing a self-reported survey. Two major research questions were addressed in this study. The first question investigated American college students' reading motivation by the Motivation for Reading Questionnaire (MRQ) variables of self-efficacy, intrinsic motivation, extrinsic motivation, and social motivation. The second question asked what variables influence American college students' motivation to read by comparing gender, classification, age, race, language backgrounds, grades in major subjects and minor subjects. Descriptive analysis indicated that the mean scores of the extrinsic motivation scale (3.07) were higher than those of intrinsic motivation (3.05), self-efficacy (3.04) and social motivation (2.35) scales. A multiple linear regression statistical analysis confirmed that gender, age, classification, grade, race, and primary language were significant factors in college students' motivation to read.
\end{abstract}

Keywords: college students, reading motivation, MRQ

\section{Introduction}

Reading is a foundational and necessary skill for successful participation in society (Kelley \& O'Decker, 2009). Motivation is a significant contributor to students' reading achievement and school success. A considerable amount of research suggests that reading requires substantial strategic effort and motivation (Guthrie et al., 2007; Guthrie et al., 2006; Huang, Orellan, \& Capps, 2016; Stipek, 2002).

Since the early 1900 s, reading motivation has become a predominant research topic and the number of studies of reading motivation has dramatically increased (Gambrell, Palmer, Codling, \& Mazzoni, 1996; Guthrie, 2008; Guthrie \& Klauda, 2014). Although the importance of motivation in the reading domain has been gradually growing worldwide, there have been only a few existing college reading motivation studies (Lin, Wong, \& McBride-Chang, 2012; Mori, 2002). These previous studies targeted English as a Foreign Language (EFL) college students; yet relatively few studies have been focused on general American college student population. The domain of reading motivation for college students has still been an underdeveloped research area (Dhanapala \& Hirakawa, 2016). Reading motivation is key to our students' success and their abilities to comprehend content, build knowledge, exercise higher level critical thinking skills, and internalize the skill

\footnotetext{
*Associate Professor, College of Education, Midwestern State University, USA.

${ }^{ \pm}$Assistant Professor, Tarleton State University, USA.
} 
sets that are necessary to productive careers. Investigation of college students' reading motivation is demanded for the field of the higher education.

Due to limited existing literature that has investigated college students' reading motivation, some scholarly publications have indicated the amount of time in reading is correlated to their reading motivation (Schutte \& Malouff, 2004). The findings from one study of 1,265 participants, discovered that American college students spent less time on both academic and nonacademic reading. More specifically, college students spent more time in social media sites than reading activities (Huang, Capps, Blacklock, \& Garza, 2014). Given these research reports, explanations of the factors associated with college students' reading motivation and engagement in reading activities need further investigation.

College students' literary skills may be another concern related to their motivation to read, Barton (2000) reported that adolescents, including college students, can quickly become non-readers when they find reading activities are too challenging or not fulfilling (Pitcher et al., 2007). Many professors have noticed that students' compliance with assigned readings is considered low (Starcher \& Proffitt, 2011). Sanoff (2006) surveyed approximately 1,100 U.S. college faculty members, and about 40 percent of the participants indicated that college freshmen are not well prepared for college-level reading and writing tasks. Many graduates lack the necessary reading skills to perform basic job-related tasks, and many employers concur with this assertion. Although some research has investigated factors (e.g., SAT verbal indicators, high school GPA's, instructional approaches) correlated with reading and academic performance, little has been done to examine whether different constructs (e.g., classification, major, and grade) affect their motivation to read (Cox, Friesner, \& Khayum, 2003; Simpson \& Rush, 2003).

In order to address the gaps in reading motivation research in the college student population, the primary goals of this study were to (1) identify the factors that influence American college students' reading motivation, and to investigate the differences in motivational components in terms of the participants' background factors such as age, gender, classification, major and grade, race, and language background, (2) to examine whether the four major motivational constructs (self-efficacy, intrinsic, extrinsic, and social motivation) correlate with college students' reading motivation.

\section{Literature Review}

Reading motivation has been viewed as a multidimensional construct by multiple constructs (Wang \& Guthrie, 2004; Wentzel, 1997; Wigfield, 1997; Wigfield \& Guthrie, 1997). Wigfield and Guthrie (1997) proposed a set of motivational constructs for the Motivation for Reading Questionnaire (MRQ), which included reading efficacy, importance, curiosity, involvement, preference for challenges, recognition, grades, competition, social sharing of reading, compliance, and work avoidance. Numerous motivation and affective surveys exist in the field such as MRQ, but the previous studies have only investigated (English as a Foreign Language) EFL students' reading motivation (Kim, 2011). 
Mori (2002) evaluated Japanese students who were EFL learners by using a motivation instrument consisting of three constructs, but Mori did not provide specific frameworks for the three-construct model. The current study is specifically designed to investigate what motivation plays a role in college students' reading according to different constructs. The study has drawn four major motivational constructs (self-efficacy, intrinsic motivation, extrinsic motivation, and social motivation) of the MRQ as a theoretical framework through which to examine whether the motivational constructs and theories can be applied to American college students.

\section{Self-Efficacy}

The construct of self-efficacy as proposed by Bandura (1997) deals with an individual's efficacy expectancies for different achievement tasks. Students' beliefs about their ability and efficacy to perform achievement tasks are crucial motivational mediators of achievement behavior (Bandura, 1997; Eccles \& Wigfield, 2002; Schunk, 2003). Being efficacious is a significant predictor of academic achievement and read increase efficacy, in turn leads to better performance (Wolters \& Pintrich, 1998). Highly efficacious students are more likely to engage in challenging activities and to be more successful when faced with difficulty (Schunk, 2003; Schunk \& Zimmerman, 1997). On the contrary, students with low self-efficacy neither produce competent performance nor engage in activities (Bandura, 1997; Linnenbrink \& Pintrich, 2003).

Often self-concept, self-efficacy, and competence belief constructs cross disciplines, but these constructs are interconnected and intertwined in the reading motivation domain (Guthrie \& Wigfield, 2000). Wigfield (2000) indicated competence beliefs refer to individuals' beliefs regarding their ability in different activities. Self-concepts refer to individuals' self-perceptions formed through learning experiences and the environment (Shavelson \& Bolus, 1982) and also includes feelings of self-worth that accompany belief in competence (Schunk \& Pajares, 2002). In recent years, the relation between self-concept and reading ability has grown stronger in the field of reading motivation (Baker, 2000). Students begin to develop an association with self-perceptions and reading skills at an early ages. By the time they reach adolescence, the relationship between their own perceptions and performance is reciprocal (Chapman \& Tunmer, 1995, 1997).

\section{Intrinsic Motivation}

The construct of intrinsic motivation refers to involvement in an activity that gives satisfaction, enjoyment, interest, or challenge to the activity itself (Deci, 1992). Students who are intrinsically motivated have an inherent interest in what they read, often achieve for their own sake, and spend more time reading (Guthrie et al., 2007; Lau, 2009; Lepper, Corpus, \& Iyengar, 2005; Wang \& Guthrie, 2004). Some experimental research suggests that increases in intrinsic reading motivation leads to more reading engagement and more curiosity relating to reading (Guthrie 
\& Cox, 2001; Guthrie, Wigfield, \& VonSecker, 2000). One aspect of intrinsic motivation is becoming totally involved in the activity, Csikszentmihalyi (1991) describes this as a "flow" experience, losing track of time and more focused on reading events.

The terms "attitudes," "interest," and "choice," are often used interchangeably along with the notion of intrinsic motivation (Mazzoni, Gambrell, \& Korkeamaki, 1999). Research found that two types of interests have been commonly associated with text comprehension (Baker, 2000). Schiefele (1991) presented the important distinction between personal and situational interest. Personal interest refers to a specific topic, is long-lasting, and "in advance of a particular situation" (p. 156). Situational interest is short-lived and "elicited in particular context" (p. 157). Classroom contexts have greatly influenced students' intrinsic motivation and engagement and have also been influenced by the degree of teachers' support of students' learning and choices (Sweet, 1997).

\section{Extrinsic Motivation}

The construct extrinsic reading motivation refers to participating in an activity due to external pressures, demands, or rewards (Deci, 1992). Students who are more extrinsically motivated often expect to receive benefits from performing the activity rather than from the activity itself (Guthrie, Schafer, Wang, \& Afflerbach, 1995). Students who have strong extrinsic orientations attempt to avoid challenging reading materials and seek to meet their goals with minimal effort (Guthrie \& Davis, 2003; Lau, 2009; Lepper et al., 2005). Some research studies have shown incentives can increase short-term attention to specific activities, but students who predominantly experience an extrinsically controlled learning environment are likely to focus on reward or recognition from others (Baker \& Wigfield, 1999; Guthrie et al., 2007).

The aspects of reading motivation based upon intrinsic and extrinsic motivation theory are also consistent, to some extent, with an individual's goal orientation toward reading. Much attention has been focused on Dweck and Leggett's (1988) theory of motivation, postulating two orientations toward learning: (a) a learning or mastery goal orientation by which students acquire knowledge and skills that lead them to become more competent learners and readers, and (b) a performance or ego goal orientation, in which individuals are eager to seek opportunities to demonstrate their skills or knowledge in a competitive approach. Goal orientations have been studied in relation to reading motivation along with the importance of consequences (Meece, 1994; Huang, Capps, Blacklock, \& Garza, 2014). Applying these concepts to the reading domain, when students focus on outperforming others, they are more likely to read texts and to do activities they know they are able to do (Guthrie \& Wigfield, 2000). By contrast, students who are more concerned with their own progress rather than with outperforming others tend to read more challenging materials (Guthrie \& Humenick, 2004). 


\section{Social Motivation}

The construct of social motivation refers to ways individuals' motivations relate to each other (Wentzel, 1996) because reading is a "social activity" within a social context (Wigfield, 2000, p. 142). For example, students read together in class and share books with others in a variety of online and offline settings. Social contexts are increasingly being recognized as important factors that influence students' reading engagement and motivation (Eccles \& Wigfield, 2002). Some researchers have begun to notice that reading is not simply an individual act of cognition, but it is also tied to the social activity of groups and cultural practices (Wigfield, et al., 2006).

Some substantial evidence indicates social interaction could enhance or diminish students' feelings of relatedness (Wigfield \& Eccles, 2002). Students who have positive social skills with their peers often tend to report doing well in school when compared with students who have low levels of peer acceptance (Berndt, 1999; Wentzel, 1997). Students who have high achievement are focused on social and academic goals in school, whereas lower achievers are focused only on social goals (Wentzel, 1994; 1996). Turner $(1995 ; 1997 ; 2001)$ has also found that both classroom learning environment and interpersonal interaction with individual students and instructors can promote or reduce students' motivation for learning and achievement.

\section{The Present Study}

Two major research questions were addressed in this study. The first question investigated American college students' reading motivation by the MRQ variables of self-efficacy, intrinsic motivation, extrinsic motivation, and social motivation. Question 2 asked what variables influence American college students' motivation to read, by comparing gender, classification, age, race, language backgrounds, grades in major subjects and minor subjects.

1. In what way do the MRQ variables of self-efficacy, intrinsic motivation, extrinsic motivation, and social motivation define American college students' reading motivation?

2. What variables influence American college students' motivation to read?

\section{Methods}

The main aim of the present study was to employ a quantitative research method to investigate American college students' reading motivation. Both descriptive and inferential statistical analyses were included to answer each question. 
Vol. 9, No. 2 Huang \& Reynolds: Facts that Influence College Students'Reading...

\section{Participants}

The study took place in a public liberal arts university in the southwestern United States during the fall semester of 2018. The participating university is organized into six colleges (education, business, fine arts, health science, social science, and science \& math), with 16 undergraduate and 9 graduate programs. Student enrollment averages around 6,000.

A total of 1,437 (533 male and 904 female) students across interdisciplinary areas voluntarily participated in the study by completing a self-reported survey. Students were recruited through instructors at the university on a voluntary basis. The classification included: freshmen (15\%), sophomores (20\%), juniors (30\%), seniors (32\%), and graduate students (3\%). The racial groups included: Caucasians (62.1\%), African Americans (17.9\%), Native Americans (0.6\%), Hispanics (9.2\%), Asians (5.4\%), Multiracial (2.2\%), and unknown (2.6\%).

\section{Instrument}

Grounded in the engagement perspective and sociocultural theories, the Motivation for Reading Questionnaire (MRQ) was originally developed by Guthrie and his colleagues to measure different dimensions of reading motivation (Baker \& Wigfield, 1999; Guthrie \& Wigfield, 2000; Wigfield \& Guthrie, 1997). It is a paper-based questionnaire with a 4-point Likert-type scale ( $1=$ very different from me, $2=$ a little different from me, $3=a$ little like me, and $4=a$ lot like me). Based on the results of the studies of Huang, Capps, Blacklock, and Garza (2014), and Lau (2004), the researchers modified the MRQ and utilized four scales with 32 questions, measuring students' self-efficacy, intrinsic motivation, extrinsic motivation, and social motivation in reading. The researchers revised the MRQ to assure that the MRQ is appropriate for college students. The researchers have asked four classes; two education classes, one math class, and one engineering class, a total of 76 students to use the new version for a trial test, but their data were not included in the current study. The new revised MRQ is listed in Appendix A.

\section{Procedures}

Before the study began, the researchers sent emails to the university's instructors/professors asking for permission to solicit students to participate in the study. Email invitations were sent to 96 instructors/professors at the university, requesting the opportunity to talk to their students during class about participation in this study. Sixty-two instructors/professors responded positively to support the study by allowing the researchers and the research assistants to visit their classes and to distribute the survey. The researchers and assistants visited participating classrooms and distributed surveys to the students. Brief instructions were given explaining how to respond to each question before surveys were given to the students. Students were assured that all data collected would remain confidential and would be used for research purposes only. Any student who was not willing to 
participate in this study was allowed to return a blank survey. Students usually spent approximately 10 minutes completing the survey anonymously.

\section{Results}

\section{Question 1: Characteristics of American College Students' Motivation to Read}

The descriptive statistics and internal consistency estimates of reliability of the variables are shown in Table 1. The findings of the descriptive statistics showed that the mean scores of the extrinsic motivation variable were higher than those of other variables. The internal consistency estimates of reliability for the self-efficacy, intrinsic motivation, extrinsic motivation, and social motivation variables in the CMRQ were $0.89,0.86,0.75$, and 0.83 respectively. In general, the variables showed strong internal consistency, as indicated by Cronbach's coefficient alpha.

Table 1. Descriptive Statistics for Variables Measured in the Study

\begin{tabular}{|l|c|c|c|c|}
\hline Measured Variable & No. of item & Mean & SD & Cronbach's $\boldsymbol{\alpha}$ \\
\hline Self-Efficacy & 8 & 3.04 & 0.65 & 0.89 \\
\hline Intrinsic Motivation & 8 & 3.05 & 0.66 & 0.86 \\
\hline Extrinsic Motivation & 8 & 3.07 & 0.48 & 0.75 \\
\hline Social Motivation & 8 & 2.35 & 0.67 & 0.83 \\
\hline
\end{tabular}

\section{Question 2: Factors Influencing College Students' Reading Motivation}

A Mann-Whitney test was conducted to determine on the four motivation scales to what extent there are differences between males and females. Results indicated that females rank significantly higher $(p<0.01)$ than males on all four motivation scales: Self-Efficacy (SE) [U=220560.5, p<0.01], Intrinsic Motivation (IM) [U=210390, p<0.001], Extrinsic Motivation (EM) [U=199457, p<0.001], and Social Motivation (SM) [U=204304.5, $\mathrm{p}<.001]$. Descriptive statistics are provided in Table 2, indicating mean ranks for both genders.

Table 2. Mean Ranks of Motivation Scale by Gender

\begin{tabular}{|l|c|c|c|c|c|}
\hline & Gender & N & Mode & Mean Rank & Sum of Ranks \\
\hline SE & Female & 904 & 4 & 741.52 & 670332 \\
\hline & Male & 533 & 3 & 680.81 & 362872 \\
\hline IM & Female & 904 & 4 & 725.77 & 680502 \\
\hline & Male & 533 & 4 & 661.73 & 352701 \\
\hline EM & Female & 904 & 4 & 764.86 & 691435 \\
\hline & Male & 533 & 4 & 641.22 & 341768 \\
\hline SM & Female & 904 & 1 & 759.5 & 686588 \\
\hline & Male & 533 & 1 & 650.31 & 346616 \\
\hline
\end{tabular}


Vol. 9, No. 2 Huang \& Reynolds: Facts that Influence College Students' Reading...

To determine the five age categories $(1=18-19$ years old, $2=20-29$ years old, $3=30-39$ years old, $4=40-49$ years old, $5=50$ and older) on the four motivation scales, results indicated significant differences on two scales; SE $[U=11.707$, $\mathrm{p}<0.05]$ and IM [U=24.907, $\mathrm{p}<0.001]$. Descriptive statistics are provided in Table 3 indicating mean ranks for age categories. Non-pairwise comparison utilizing Tukey's HSD indicates that respondents age 30-39 rated items in SE $(\mathrm{p}<0.05)$ and IM higher $(\mathrm{p}<0.01)$ than those $18-19$ years old. In addition, respondents age 30-39 years old also ranked higher $(\mathrm{p}<0.05)$ than those $20-29$ years old on IM.

Table 3. Mean Ranks of Motivation Scale by Age

\begin{tabular}{|l|c|c|c|c|}
\hline & Age & Mode & N & Mean Rank \\
\hline SE & 1 & 3 & 275 & 682.33 \\
\hline & 2 & 3 & 1009 & 714.36 \\
\hline & 3 & 4 & 108 & 824.26 \\
\hline & 4 & 4 & 34 & 824.13 \\
\hline & 5 & 3 & 10 & 737.40 \\
\hline IM & 1 & 4 & 275 & 656.81 \\
\hline & 2 & 4 & 1009 & 715.79 \\
\hline & 3 & 4 & 108 & 853.97 \\
\hline & 4 & 4 & 34 & 852.57 \\
\hline & 5 & 4 & 10 & 769.45 \\
\hline EM & 1 & 4 & 275 & 720.62 \\
\hline & 2 & 4 & 1009 & 718.00 \\
\hline & 3 & 4 & 108 & 742.67 \\
\hline & 4 & 4 & 34 & 662.97 \\
\hline & 5 & 4 & 10 & 637.90 \\
\hline SM & 1 & 3 & 275 & 767.42 \\
\hline & 2 & 1 & 1009 & 699.91 \\
\hline & 3 & 1 & 108 & 772.08 \\
\hline & 4 & 1 & 34 & 711.91 \\
\hline & 5 & 1 & 10 & 692.80 \\
\hline
\end{tabular}

In determining the seven categories of race (1=White/Non-Hispanic, $2=$ Black/ African American, 3=Asian, 4=Latino/Hispanic, 5=Native American, 6=Multiracial, $7=$ Other) on the four motivation scales, the results indicated a significant difference on two scales; SE [U=12.59, $\mathrm{p}=0.05]$ and $\mathrm{SM}[\mathrm{U}=8.4, \mathrm{p}<0.05]$. Asian students had lowest scores in SE and EM. In contrast, African students had highest scores in SE and EM. Descriptive statistics are provided in Table 4 indicating mean ranks for ethnicity. 
Table 4. Mean Ranks of Motivation Scale by Race/Ethnicity

\begin{tabular}{|c|c|c|c|c|}
\hline & Race & Mode & $\mathbf{N}$ & Mean Rank \\
\hline \multirow[t]{7}{*}{ SE } & 1 & 3 & 893 & 731.73 \\
\hline & 2 & 3 & 257 & 741.19 \\
\hline & 3 & 3 & 78 & 593.54 \\
\hline & 4 & 3 & 132 & 665.51 \\
\hline & 5 & 3 & 8 & 685.69 \\
\hline & 6 & 3 & 32 & 719.08 \\
\hline & 7 & 4 & 37 & 720.11 \\
\hline \multirow[t]{7}{*}{ IM } & 1 & 4 & 893 & 707.96 \\
\hline & 2 & 4 & 257 & 757.36 \\
\hline & 3 & 4 & 78 & 729.53 \\
\hline & 4 & 4 & 132 & 705.72 \\
\hline & 5 & 4 & 8 & 780.94 \\
\hline & 6 & 4 & 32 & 682.77 \\
\hline & 7 & 4 & 37 & 762.26 \\
\hline \multirow[t]{7}{*}{ EM } & 1 & 4 & 893 & 717.15 \\
\hline & 2 & 4 & 257 & 743.08 \\
\hline & 3 & 4 & 78 & 658.65 \\
\hline & 4 & 4 & 132 & 703.67 \\
\hline & 5 & 4 & 8 & 710.50 \\
\hline & 6 & 4 & 32 & 764.27 \\
\hline & 7 & 4 & 37 & 741.03 \\
\hline \multirow[t]{7}{*}{ SM } & 1 & 1 & 893 & 711.75 \\
\hline & 2 & 1 & 257 & 765.50 \\
\hline & 3 & 3 & 78 & 763.78 \\
\hline & 4 & 1 & 132 & 667.14 \\
\hline & 5 & 1 & 8 & 806.44 \\
\hline & 6 & 1 & 32 & 650.56 \\
\hline & 7 & 1 & 37 & 701.80 \\
\hline
\end{tabular}

In determining the five categories of student classification $(1=$ freshman, $2=$ sophomore, $3=$ junior, $4=$ senior, $5=$ graduate) on the four motivation scales, results indicated a significant difference on two scales; $S E[U=14.452, p<0.01]$ and IM [U=13.816, p<0.001]. Graduate respondents ranked higher on SE and IM. Freshmen respondents ranked higher on SM. More detailed descriptive statistics are provided in Table 5 indicating mean ranks for classification.

Of the four categories of primary language (1=English, 2=Spanish, 3=Chinese, $4=$ Other) on the four motivation scales, results indicated a significant difference on three scales; SE [U= 13.938, $\mathrm{p}<0.01]$ and IM [U=9.6, $\mathrm{p}<0.001]$ and SM $[\mathrm{U}=18.838, \mathrm{p}<0.001]$. The respondents whose native language was English ranked higher on SE and IM. On the contrary, Chinese students in this study ranked lowest in SE. More detailed descriptive statistics are provided in Table 6 indicating mean ranks for primary language. 
Vol. 9, No. 2 Huang \& Reynolds: Facts that Influence College Students' Reading...

Table 5. Mean Ranks of Motivation Scale by Classification

\begin{tabular}{|l|c|c|c|c|}
\hline & Class & Mode & N & Mean Rank \\
\hline SE & 1 & 3 & 192 & 640.09 \\
\hline & 2 & 3 & 286 & 707.87 \\
\hline & 3 & 4 & 433 & 725.02 \\
\hline & 4 & 3 & 448 & 729.92 \\
\hline & 5 & 4 & 74 & 826.67 \\
\hline IM & & & 1433 & \\
\hline & 1 & 4 & 192 & 654.54 \\
\hline & 2 & 4 & 286 & 680.94 \\
\hline & 3 & 4 & 433 & 723.22 \\
\hline & 4 & 4 & 448 & 747.54 \\
\hline & 5 & 4 & 74 & 797.09 \\
\hline EM & & & 1433 & \\
\hline & 1 & 4 & 192 & 694.81 \\
\hline & 2 & 4 & 286 & 693.67 \\
\hline & 3 & 4 & 433 & 745.83 \\
\hline & 4 & 4 & 448 & 714.28 \\
\hline & 5 & 4 & 74 & 712.53 \\
\hline SM & & & 1433 & \\
\hline & 1 & 3 & 192 & 748.25 \\
\hline & 2 & 1 & 286 & 715.25 \\
\hline & 3 & 1 & 433 & 703.22 \\
\hline & 4 & 1 & 448 & 713.72 \\
\hline & 5 & 1 & 74 & 743.02 \\
\hline
\end{tabular}

Table 6. Mean Ranks of Motivation Scale by Primary Language

\begin{tabular}{|l|c|c|c|c|}
\hline & PrimLang & Mode & N & Mean Rank \\
\hline SE & 1 & 3 & 1335 & 728.95 \\
\hline & 2 & 3 & 34 & 599.18 \\
\hline & 3 & 2 & 10 & 446.25 \\
\hline & 4 & 4 & 58 & 607.32 \\
\hline & & & 1437 & \\
\hline IM & 1 & 4 & 1335 & 725.16 \\
\hline & 2 & 3 & 34 & 532.25 \\
\hline & 3 & 3 & 10 & 586.05 \\
\hline & 4 & 4 & 58 & 709.68 \\
\hline & & & 1437 & \\
\hline EM & 1 & 4 & 1335 & 720.69 \\
\hline & 2 & 4 & 34 & 683.50 \\
\hline & 3 & 3 & 10 & 480.70 \\
\hline & 4 & 4 & 58 & 741.95 \\
\hline & & & 1437 & \\
\hline SM & 1 & 1 & 1335 & 714.96 \\
\hline & 2 & 1 & 34 & 553.88 \\
\hline & 4 & 3 & 10 & 730.50 \\
\hline & & 3 & 58 & 906.82 \\
\hline
\end{tabular}


In to determining to what extent there were significant differences between reported grades, results indicated a significant difference on three scales: SE $[\mathrm{U}=38.394, \mathrm{p}<0.001]$ and $\mathrm{IM}[\mathrm{U}=16.924, \mathrm{p}<0.01]$ and $\mathrm{EM}[\mathrm{U}=29.847, \mathrm{p}<0.001]$. The respondents who received an "A" ranked higher in four motivational scales. More detailed descriptive statistics are provided in Table 7 indicating mean ranks for grades in major.

Table 7. Mean Ranks of Motivation Scale by Grades in Major

\begin{tabular}{|l|c|c|c|c|}
\hline & Major & Mode & N & Mean Rank \\
\hline SE & A & 4 & 673 & 779.12 \\
\hline & B & 3 & 668 & 677.70 \\
\hline & C & 3 & 93 & 596.50 \\
\hline & D & 1 & 2 & 316.00 \\
\hline IM & F & 1 & 1 & 242.50 \\
\hline & A & 4 & 673 & 759.05 \\
\hline & B & 4 & 668 & 691.06 \\
\hline & C & 3 & 93 & 636.85 \\
\hline & D & 2 & 2 & 649.50 \\
\hline EM & F & 2 & 1 & 207.00 \\
\hline & A & 4 & 673 & 772.31 \\
\hline & B & 4 & 668 & 674.68 \\
\hline & C & 4 & 93 & 649.95 \\
\hline & D & 3 & 2 & 659.50 \\
\hline SM & F & 4 & 1 & 985.00 \\
\hline & A & 1 & 673 & 739.96 \\
\hline & B & 1 & 668 & 710.26 \\
\hline & C & 1 & 93 & 632.19 \\
\hline & D & 2 & 2 & 859.50 \\
\hline & F & 1 & 1 & 242.00 \\
\hline
\end{tabular}

Results indicated a significant difference on three scales, SE $[\mathrm{U}=53.144$, $\mathrm{p}<0.001]$ and $\mathrm{IM}[\mathrm{U}=23.053, \mathrm{p}<0.01]$ and $\mathrm{EM}[\mathrm{U}=43.203, \mathrm{p}<0.001]$ when it determined grades in non-major. The respondents who received an " $\mathrm{A}$ " ranked higher in four motivational scales. More detailed descriptive statistics are provided in Table 8 indicating mean ranks for grades in minor.

Multiple linear regression was employed to help determine which of ten variables including, gender, age, race, classification (Class), primary language (PrimLang), grades in major (Gradesmaj), grades in nonmajor (Gradesnonma), intrinsic motivation (IM), extrinsic motivation (EM) and social motivation (SM).

The ten variables together produced an adjusted $R^{2}$ of $0.255[\mathrm{~F}(10,1426)=$ $50.927, \mathrm{p}<0.001]$ for the predication self-efficacy. The predictors with the lowest non-significant regression coefficient were moved and the predication self-efficacy another regression analysis was conducted for the predication social motivation which had an adjusted $R^{2}$ of $0.276(\mathrm{~F}(4,1432)=136.263$, p <0.001). Therefore, the significant contributing factors to self-efficacy (see Table 9) include primary language, grades in major, grades in non-major, intrinsic motivation, extrinsic motivation, and social motivation. 
Vol. 9, No. 2 Huang \& Reynolds: Facts that Influence College Students' Reading...

Table 8. Mean Ranks of Motivation Scale by Grades in Minor

\begin{tabular}{|l|c|c|c|c|}
\hline & Minor & Mode & N & Mean Rank \\
\hline SE & A & 4 & 673 & 779.12 \\
\hline & B & 3 & 668 & 677.70 \\
\hline & C & 3 & 93 & 596.50 \\
\hline & D & 1 & 2 & 316.00 \\
\hline IM & F & 1 & 1 & 242.50 \\
\hline & A & 4 & 673 & 759.05 \\
\hline & B & 4 & 668 & 691.06 \\
\hline & C & 3 & 93 & 636.85 \\
\hline & D & 1 & 2 & 649.50 \\
\hline EM & F & 1 & 1 & 207.00 \\
\hline & A & 4 & 673 & 772.31 \\
\hline & B & 4 & 668 & 674.68 \\
\hline & C & 4 & 93 & 649.95 \\
\hline & D & 4 & 2 & 659.50 \\
\hline SM & F & 4 & 1 & 985.00 \\
\hline & A & 1 & 673 & 739.96 \\
\hline & B & 1 & 668 & 710.26 \\
\hline & C & 1 & 93 & 632.19 \\
\hline & D & 1 & 2 & 859.50 \\
\hline
\end{tabular}

Table 9. Regression Model for the Six Variables Predicting Self-Efficacy

\begin{tabular}{|l|c|c|c|c|c|}
\hline & B & SEB & $\boldsymbol{\beta}$ & $\mathbf{t}$ & $\mathbf{p}$ \\
\hline PrimLang & -0.128 & 0.032 & -0.092 & -4.032 & 0.000 \\
\hline Gradesmaj & -0.113 & 0.034 & -0.081 & -3.359 & 0.000 \\
\hline Gresnonmaj & -0.123 & 0.031 & -0.097 & -3.983 & 0.000 \\
\hline IM & 0.357 & 0.023 & 0.386 & 15.644 & 0.000 \\
\hline EM & 0.084 & 0.027 & 0.073 & 3.081 & 0.002 \\
\hline SM & 0.091 & 0.020 & 0.111 & 4.626 & 0.000 \\
\hline
\end{tabular}

To predict the dependent variable intrinsic motivation (IM), the ten variables together produced an adjusted $R^{2}$ of $.280[\mathrm{~F}(10,1426)=55.501, \mathrm{p}<0.001]$ for the predication intrinsic motivation. The predictors with the lowest non-significant regression coefficient were removed and another regression analysis was conducted for the predication social motivation which had an adjusted $R^{2}$ of 0.276 $(\mathrm{F}(4,1432)=136.263, \mathrm{p}<0.001)$. Therefore, the significant contributing factors to intrinsic motivation (see Table 10) include age, self-efficacy, extrinsic motivation, and social motivation.

Table 10. Regression Model for the Four Variables Predicting Intrinsic Motivation

\begin{tabular}{|l|c|c|c|c|c|}
\hline & B & SEB & $\boldsymbol{\beta}$ & t & p \\
\hline Age & 0.107 & 0.032 & 0.076 & 3.355 & 0.001 \\
\hline SE & 0.408 & 0.025 & 0.378 & 16.007 & 0.000 \\
\hline EM & 0.101 & 0.029 & 0.081 & 3.523 & 0.000 \\
\hline SM & 0.207 & 0.021 & 0.235 & 10.026 & 0.000 \\
\hline
\end{tabular}


To predict the dependent variable, extrinsic motivation $(\mathrm{EM})$, the ten variables together produced an adjusted $R^{2}$ of $0.086[\mathrm{~F}(10,1426)=13.455, \mathrm{p}<0.001]$ for the predication extrinsic motivation. The predictors with the lowest non-significant regression coefficient were removed and another regression analysis was conducted for the predication social motivation which had an adjusted $R^{2}$ of 0.154 $(\mathrm{F}(6,1430)=21.361, \mathrm{p}<0.001)$. Therefore the significant contributing factors to extrinsic motivation (see Table 11) include gender, self-efficacy, intrinsic motivation, social motivation, grades in major and grades in non-major.

Table 11. Regression Model for the Six Variables Predicting Extrinsic Motivation

\begin{tabular}{|l|c|c|c|c|c|}
\hline & $\mathbf{B}$ & SEB & $\boldsymbol{\beta}$ & $\mathbf{t}$ & $\mathbf{p}$ \\
\hline Gender & -0.146 & 0.04 & -0.094 & -3.625 & 0.000 \\
\hline SE & 0.081 & 0.025 & 0.093 & 3.189 & 0.001 \\
\hline IM & 0.072 & 0.024 & 0.089 & 3.015 & 0.003 \\
\hline SM & 0.054 & 0.019 & 0.076 & 2.780 & 0.006 \\
\hline Gradesmaj & -0.084 & 0.033 & -0.069 & -2.587 & 0.010 \\
\hline Gradesnonmaj & -0.102 & 0.03 & -0.092 & -3.383 & 0.001 \\
\hline
\end{tabular}

To predict the dependent variable, social motivation (SM); the ten variables together produced an adjusted $R^{2}$ of $0.154[\mathrm{~F}(10,1426)=27.116, \mathrm{p}<0.001]$ for the predication social motivation. The predictors with the lowest non-significant regression coefficient were removed and another regression analysis was conducted for the predication social motivation which had an adjusted $R^{2}$ of 0.153 (F (6, $1430)=44.310, \mathrm{p}<0.001)$. Therefore, the significant contributing factors to social motivation (see Table 12) include gender, age, primary language, self-efficacy, intrinsic motivation, and extrinsic motivation.

Table 12. Regression Model for the Six Variables Predicting Social Motivation

\begin{tabular}{|l|c|c|c|c|c|}
\hline & B & SEB & $\boldsymbol{\beta}$ & t & p \\
\hline Gender & -0.195 & 0.054 & -0.089 & -3.617 & 0.000 \\
\hline Age & -0.105 & 0.039 & -0.065 & -2.655 & 0.008 \\
\hline PrimLang & 0.182 & 0.041 & 0.107 & 4.382 & 0.000 \\
\hline SM & 0.156 & 0.034 & 0.127 & 4.602 & 0.000 \\
\hline IM & 0.308 & 0.031 & 0.271 & 9.8 & 0.000 \\
\hline EM & 0.09 & 0.035 & 0.064 & 2.54 & 0.011 \\
\hline
\end{tabular}

\section{Discussion}

The descriptive findings supported the reliability of the MRQ in measuring the reading motivation of American college students. Students scored most highly on extrinsic motivation followed by intrinsic motivation, self-efficacy and social motivation. This suggests that extrinsic motivation played a positive and significant role in college students' motivation to read. Grades are often used as a benchmark to measure students' learning outcome because taking tests or other types of assessments is an indispensable part of a variety of educational settings in the U.S. including college contexts (e.g., Huang, Capps, Blacklock, \& Garza, 2014; Huang, 
Orellan, \& Capps, 2016). The inferential statistical findings also provided support that grades for both major and non-major can significantly impact students' selfefficacy, intrinsic, extrinsic, and social motivation. The results are consistent with previous research suggesting grades played an incredibly significant role in motivating students to read (Yeung, Lau, \& Nie, 2011; Yeung \& Mclnerney, 2004). This aspect of reading motivation has validated findings by Wigfield, Guthrie, Tonks, and Perencevich (2004) that stated grades are still enormously powerful forces and motivators in students' lives. Students also value grades as an important indicator of success status (Huang, Capps, Blacklock, \& Garza, 2014). Recognition, competition, and grades may play prominently in their motivation for reading or finishing tasks (e.g., Wigfield \& Guthrie, 1997; Wigfield, Guthrie, Tonks, \& Perencevich, 2004).

This aspect of extrinsic motivation has validated the findings of several previous studies showing that extrinsic motivators are still enormously powerful forces in students' lives (e.g, Huang, 2013; Huang, Capps, Blacklock,„\& Garza, 2014; Schaffner, Schiefele, \& Ulferts, 2013; Schiefele, Schaffner, Moller, \& Wigfield, 2012; Wigfield, Guthrie, Tonks, \& Perencevich, 2004). Although extrinsic motivation has been shown as a negative motivational orientation in elementary/ middle school contexts, it may be a positive motivating force for college students because they need to complete all assignments in order to receive a passing grade to finish college degrees in a timely fashion or receive better GPAs for their future career search (Barton, 2000; Huang Huang, Orellan, \& Capps, 2016).

The mean score of the intrinsic motivation scale indicates that students in this study were strongly motivated to read through intrinsic motivation, and the findings are also consistent with numerous studies indicating that intrinsic motivation is essential for learning in a variety of school contexts (e.g., Guthrie \& Klauda, 2014; Mucherah \& Yoder, 2008; Schiefele et al., 2012; Wigfield et al., 2006). More specially, college students have more choices with subjects and major areas so they can set greater goals for themselves to achieve. Reading choice that related to their major areas may affect reading engagement and intrinsic motivation (Huang, Capps, Blacklock, \& Garza, 2014).

Social motivation construct had the lowest scores in this study. The findings were consistent with the findings of several existing studies that indicated students did not seem to be motivated to read for social reasons (e.g., Guthrie et al., 2007; Wigfield \& Wentzel, 2007). Having a part-time job may be a possible factor affecting U.S. college students' reading social motivation. Approximately half of full-time, traditional-aged college students have part-time jobs (Huang, Capps, Blacklock, \& Garza, 2014; Perna, 2010). Another possible factor is Internet technologies, especially with its continuous development and rapid evolution, giving college students a space for making connections and adapting their communication within broad social networks (e.g., Gee, 2007; Paul, Baker, \& Cochran, 2012). The mean scores of items 15 ("I often enjoy reading information including online reading materials" and 16 "I like reading different types of books such as E-books" of the MRQ were 3.65 which was higher than the rest of the survey questions. This may lead college students to devote more time to accessing digital-media information through different social media platforms than sharing 
information from traditional printed texts or reading resources individually (Hsu \& Wang, 2011).

Evidence from both descriptive and inferential statistical analysis in this study showed that gender, age, classification, race background, primary language, and grades made significant differences on the four motivation constructs. Females scored significantly higher than males on the four scales. The evidence indicated gender still played a role in college students' motivation to read. The findings are congruent with results from several studies from elementary to adolescents on the gender gap in reading motivation (e.g., Marinak \& Gambrell, 2010; MerisuoStorm, 2006). In this study, the older college students (ages 30-39) had higher scores than other groups (ages 18-19 and 20-29) on the self-efficacy and intrinsic motivation scales. Graduate students in this study displayed higher scores in each scale. Unlike traditional college students, the older ones probably exhibited high levels of effort in reading difficulty, engagement in reading tasks, and were more goal oriented, as well as being more willing to share with others related to any course activities. The results are consistent with some existing research studies that say age can have an impact on reading motivation effort (e.g., Gilda, Hess, \& Smith, 2013).

It is a notable finding that freshmen had higher scores on social motivation. Possibly leaving home for a residential college can be both exciting and challenging for the first-year experience in institutions of higher education. The transition to college can make college freshmen feel anxious in the new environment (Yang, 2016). Many universities have created either online or offline social networking programs to lower the level of loneliness and anxiety, better social support and friendship quality among first-year college students. Social interaction becomes the more prevalent channel for freshmen students (Mounts, Valentiner, Anderson, \& Boswell, 2006).

African American students made higher scores on self-efficacy and intrinsic motivation than other groups. The findings were different from the findings of Guthrie, Coddington and Wigfield (2009) who reported that intrinsic motivation correlated lower with reading achievement for African American students than for Caucasian students. African American students in this study were strongly motivated to read, which is consistent with some of the previous studies that said African American students have already recognized the value of education and its power for transforming lives and communities. Ensuring that they can take advantage of college educational opportunities is critical to their family and community (e.g., Huang, Capps, Blacklock, \& Garza, 2014; The Institute for Higher Education Policy, 2010).

It is interesting note that Asian students had lower scores on the self-efficacy scale than other groups. This is consistent with some previous studies showing that Asian students have lower self-efficacy and self-esteem than Western students, perhaps because traditional Confucianism emphasizes humbleness and modesty. Asian students have also been told not to make good comments about their own performance (e.g., Hong, 2001; Salili, 1995; Salili, Chiu, \& Lai, 2001). In contrast, Asian students had the highest scores in the social motivation than those in other scales. The strong collectivistic orientation of Asian students influences their 
achievement behavior, and success is defined in terms of recognition and smooth social relationships. Asian students are socialized to value education. The findings were consistent with some researchers' speculation that social motivation is quite important because Asian students are expected to socialize under a collectivist culture (e.g., Lau, 1997; Salili, 1995; Yang, 1997).

In this study, students whose primary language is English scored higher in the four scales. Kim (2011) also found reading motivation scales were significantly different between native speakers and English Language Learners. Since language functions can take place in both oral and written communication, reading academic books, or in real-life conversations, knowing how to use these language functions allows students to participate fully in these conversations. When students are fully language functional in a variety of contexts, they should develop confidence and a positive attitude toward learning. Language also strongly links reading and writing (e.g., Hill \& Miller, 2013). In contrast, Chinese students had lower scores in the four scales than other language groups. Unlike native English speakers, Chinese students are required to use additional effort (the time spent in study), desire (the yearning to become also requires effort) and affect (the emotional reactions of learning toward studying) (e.g., Carrio-Pastor \& Mestre, 2014; Gardner, 1982; Siskin, 2008). A wide array of research indicates that it generally takes five to seven years for English Language Learners to develop academic language proficiency (e.g., Peregoy \& Boyle, 2017). As second language learners, they probably do not see themselves as self-efficacious learners. They especially need to have a higher level of language skills at the college level to do course related work or socializing with others, knowing the culture of the contexts in which they find themselves.

\section{Limitations and Future Study}

While the findings of the study have enhanced our understanding of American college students' reading motivation, four limitations of this study and suggestions for future research should be addressed. First, the study was limited to only one campus with its student population. Results may not be generalized to the college student population in the U.S. Second, the survey did not include students' majors and geographical information. In the future, researchers may consider adding these two items to the survey and determine what impact college students' majors and geographical background information have on their motivation to read. Third, the researchers have revised the MRQ and conducted a trial test assessing the reliability and validity for college students. The future research study may consider revising some questions such as what types of online reading materials and online reading activities via social media sites are related to reading motivation. Fourth, reading researchers have predominantly employed a quantitative research method; we still have limited understanding of the "why." Future studies should consider adopting qualitative or mixed methodologies to explore reading motivation in school, home, and community contexts so that we can have a better 
understanding of American college students' motivation to read. More studies of this kind are needed.

\section{Implications}

Student motivation is a key factor in successful reading and academic achievement. Evidence suggests that students who read more also read better than those who read less (e.g., Mokhtari, Reichard, \& Gardner, 2009). Reading can impact social life and economic prosperity. Therefore, encouraging students to engage in academic (or "school-related") and extracurricular reading (or "free voluntary reading not related to academic work") is critically important for students to develop reading interests and academic achievement (Huang, Orellan, \& Capps, 2016; Mokhtari, Reichard, \& Gardner, 2009). To foster students' reading motivation and engagement in reading activities, college professors could promote some reading activities for college students such as a literature circle. Professors and students discuss what types of books and genres they are interested in or subject related books (technology, science, and mathematics, etc.) and then provide a reading list for them to select. Have them discuss the book they select biweekly. Each student should take a different role when they form a literature circle, for example, discussion director, literary luminary, vocabulary enricher, summarizer, illustrator, and connector. Professors could provide a "show and tell" time to present their book by the end of the semester. Literature circles can be a place for cooperative learning and provide a way for college students to engage in critical thinking and reflection as they read, discuss, and respond to books. Students can rethink their understanding as they construct meaning with other readers. Literature circles can be implemented to cross interdisciplinary areas and also promote reading motivation.

The results of the present study illustrated several factors influencing American college students' reading motivation. With the advent of the Internet, information can be transmitted anywhere around the world (Mohamed et al., 2012). The use of Internet technologies has changed students' reading patterns and motivation to read. The definition of reading has also been changed by new technologies (e.g., online learning tools, social media sites) in varied social and academic contexts. College professors have adopted and used online tools in traditional learning environments. Particularly, college professors could create online discussion and presentation activities, and then divide the class into groups with different roles (e.g., evaluating a text, critiquing an event, designing projects) with one group responsible for creating questions, another for responding to questions, and still another for summarizing and commenting. Such roles can be changed throughout the semester, so each student has opportunities to work in each capacity. Having students take turns with different roles in online discussion could potentially engage them in collaborative online contexts and promote social practice.

College professors and instructors may consider interconnecting traditional literacies with social media sites (e.g., Facebook, Instagram, Twitter, Wikis, 
Youtube) by building an e-learning environment and requiring students to participate and collaborate for educational purposes. The use of social media applications in teaching and learning has expanded from merely recreational purposes to become a learning supplement in the classroom environment (Elavsky, Mislan, \& Elavsky, 2011). These applications have the potential to draw students' attention away from academic reading, extracurricular reading, and even lecture content (Abe \& Jordan, 2013). Thus, professors and instructors may consider creating hybrid or virtual classrooms to promote formal and informal learning experiences. For example, professors and instructors can use the regular class time to organize extracurricular programs or book clubs whose meetings and discussions take place online, outside of class time. This type of a blended learning approach provides opportunities for student engagement inside and outside of class (Khalil, Abdel Megui, \& Elkhider, 2018). This may help make college students more willing to spend their time reading online and do offline projects, so they are more engaged in learning in different contexts.

\section{Conclusions}

In summary, this study has shed light on factors that influence college students' reading motivation. The mean of the extrinsic motivation scale was higher than intrinsic motivation, self-efficacy and social motivation. The results of a multiple linear regression indicated that gender, age, classification, grade, race, and primary language were significant factors in college students' motivation to read. This study was well positioned with a solid data set about students' motivation to read in the higher education and college populations. It not only added to an understanding of how these constructs contribute to a learner's motivation to read, but also provides greater depth in the understanding of what factors impact college students' reading motivation. Specifically, internet technologies offer space for college students to connect with others, integrate learning experiences, support collaboration and change academic contexts. This shift seems to have affected college students' reading interests, activities, and motivation and is fertile ground for encouraging substantial strategic effort and motivation to read.

\section{References}

Abe, P., \& Jordan, N. A. (2013). Integrating Social Media into the Classroom Curriculum. About Campus, 18(1), 16 -20.

Baker, L. (2000). Building the Word-Level Foundation for Engaged Reading. In L. Baker., M. J. Dreher., \& J. Guthrie (eds.), Engaging Young Readers: Promoting, Achievement, and Motivation (pp. 17-42). New York: The Guilford Press.

Baker, L., \& Wigfield, A. (1999). Dimensions of Children's Motivation for Reading and their Relations to Reading Activity and Reading Achievement. Reading Research Quarterly, 34(4), 152-177.

Bandura, A. (1997). Self-Efficacy: The Exercise of Control. New York: W. H. Free man. 
Barton, P. E. (2000). What Jobs Require: Literacy, Education, and Training, 1940-2006. Washington, DC: Educational Testing Service.

Berndt, T. J. (1999). Friends' Influence on Students' Adjustment to School. Educational Psychologist, 34(1), 15-28.

Carrio-Pastor, M. L., \& Mestre, E. V. (2014). Motivation in Second Language Acquisition. Procedia-Social and Behavioral Sciences, 116(Feb), 240-244.

Chapman, J. W., \& Tunmer, W. E. (1995). Development of Young Children's Reading Concepts: An Examination of Emerging Subcomponents and their Relationship with Reading Achievement. Journal of Educational Psychology, 87(1), 154-167.

Chapman, J. W., \& Tunmer, W. E. (1997). A Longitudinal Study of Beginning Reading Achievement and Reading Self-Concept. British Journal of Educational Psychology, 67(3), 279-291.

Cox, S. R., Friesner, D. L., \& Khayum, J. (2003). Do Reading Skills Courses Help Underprepared Readers Achieve Academic Success in College? Journal of College Reading and Learning, 33(2), 170-196.

Csikszentmihalyi, M. (1991). Literacy and Intrinsic Motivation. In S. R. Graubard (ed.), Literacy (pp.115-140). New York: Noonday.

Deci, E. L. (1992). The Relation of Interest to the Motivation of Behavior: A SelfDetermination of Theory Perspective. In K. A. Renninger, S. Hidi, \& A. Krapp (eds.), The Role of Interest in Learning and Development (pp.43-70). Hillsdale, NJ: Erilbaum.

Dhanapala, K. V., \& Hirakawa, Y. (2016). L2 Reading Motivation among Sri Lankan University Students. Reading Psychology, 37(2), 202-229.

Dweck, C., \& Leggett, E. (1988). A Social-Cognitive Approach to Motivation and Personality. Psychological Review, 95(2), 256-273.

Eccles, J. S., \& Wigfield, A. (2002). Motivational Beliefs, Values, and Goals. Annual Review of Psychology, 53(1), 109-132.

Elavsky, C. M., Mislan, C., \& Elavsky, S. (2011). When Talking Less is More: Exploring Outcomes of Twitter Usages in the Large-Lecture Hall. Learning, Media and Technology, 36(3), 215-233.

Gambrell, L. B., Palmer, B. M., Codling, R. M., \& Mazzoni, S. A. (1996). Assessing Motivation to Read. The Reading Teacher, 49, 518-533.

Gardner, R. C. (1982) Language Attitudes and Language Learning. In E. Bouchard Ryan, \& H. Giles (eds.), Attitudes towards Language Variation (pp.132-147). London: Edward Arnold.

Gee, J. P. (2007). Social Linguistics and Literacies: Ideology in Discourse. London, UK: Rutledge.

Gilda, E. Hess, T., \& Smith, B. T. (2013). The Impact of Age and Motivation on Cognitive Effort: Implications for Cognitive Engagement in Older Adulthood. Psychology and Aging, 28(2), 495-504.

Guthrie, J. T. (2008). Engaging Adolescents in Reading. Thousand Oaks, CA: Corwin Press.

Guthrie, J. T., Coddington, C. S., \& Wigfield, A. (2009). Profiles of Reading Motivation among African American Students and Caucasian Students. Journal of Literacy Research, 41(3), 317-353.

Guthrie, J. T., \& Cox, K. E. (2001). Classroom Conditions for Motivation and Engagement in Reading. Educational Psychology Review, 13(3), 283-302.

Guthrie, J. T., \& Davis, M. H. (2003). Motivating Struggling Readers in Middle School through an Engagement Model of Classroom Practice. Reading and Writing Quarterly, 19(1), 59-85. 
Vol. 9, No. 2 Huang \& Reynolds: Facts that Influence College Students' Reading...

Guthrie, J. T., Hoa, A. L., Wigfield, A., Tonks, S. M., Humenick, N, M., \& Littles, E. (2007). Reading Motivation and Reading Comprehension Growth in the Later Elementary Years. Contemporary Educational Psychology, 32(3), 282-313.

Guthrie, J. T., \& Humenick, N. M. (2004). Motivating Students to Read: Evidence for Classroom Practices that Increase Motivation and Achievement. In P. Mccardle., \& V. Chhabra (eds.), The voice of evidence in reading research (pp. 329-354). Baltimore: Paul Brookes Publishing.

Guthrie, J. T., \& Klauda, S. L. (2014). Effects of Classroom Practices on Reading Comprehension, Engagement, and Motivations for Adolescents. Reading Research Quarterly, 49(4), 387-416.

Guthrie, J. T., Schafer, W., Wang Y. Y., \& Afflerbach, P. (1995). Relationships of Instruction to Amount of Reading: An Exploration of Social, Cognitive, and Instructional Connections. Reading Research Quarterly, 30(1), 8-30.

Guthrie, J. T., Wigfield, A. Humenick, N. M., Perencevich., Taboada, A., \& Barbosa, P. (2006). Influences of Stimulating Tasks on Reading Motivation and Comprehension. The Journal of Educational Research, 99(4), 232-246.

Guthrie, J. T., \& Wigfield, A. (2000). Engagement and Motivation in Reading. In M. L.Kamil., P. B. Mosenthal., P. D. Pearson., \& R. Barr (eds.), Handbook of Reading Research ( $3^{\text {rd }}$ Edition, pp. 403-422). Mahwah, New Jersey: Lawrence Erlbaum Association.

Guthrie, J. T., Wigfield, A., \& VonSecker, C. (2000). Effects of Integrated Instruction on Motivation and Strategy Use in Reading. Journal of Educational Psychology, 92(2), 331-341.

Hill, J. D., \& Miller, K. B. (2013). Classroom Instruction that Works with English Language Learners. $2^{\text {nd }}$ Edition. Alexandria, VA: ASCD.

Hong, Y. (2001). Chinese Students' and Teachers' Inferences of Effort and Ability. In S. Farideh, \& C. Chi (eds.), Student Motivation: The Culture and Context of Learning (pp. 105-120). Plenum Series on Human Exceptionality.

Hsu, H-Y., \& Wang, S. W. (2011). The Impact of Using Blogs on College Students' Reading Comprehension and Learning Motivation. Literacy Research and Instruction, $50(1), 69-88$.

Huang, S. H. (2013). Factors Affecting Chinese Middle School Students' Reading Motivation. Reading Psychology, 34(2), 148-181.

Huang, S. H., Capps, M., Blacklock, J., \& Garza, M. (2014). Reading Habits of College Students in USA. Reading Psychology, 35(5), 437-467.

Huang, S. H., Orellan, P., \& Capps, M. (2016). U. S. and Chilean College Students' Reading Practice: A Cross-Cultural Perspective. Reading Research Quarterly, 51(4), 455-471.

Kelley, M. J., \& O'Decker, E. (2009). The Current State of Motivation to Read among Middle School Students. Reading Psychology, 30(5), 466-485.

Khalil, M. K., Abdel Meguid, E. M., \& Elkhider, I. A. (2018). Teaching of Anatomical Sciences: A Blended Learning Approach. Clinical Anatomy, 31(3), 323-329.

Kim, K. J. (2011). Reading Motivation in Two Languages: An Examination of EFL College Students in Korea. Read Writ, 24(8), 861-881.

Lau, K. L. (2004). Construction and Initial Validation of the Chinese Reading Motivation Questionnaire. Educational Psychology, 24(6), 845-865.

Lau, K. L. (2009). Reading Motivation, Perceptions of Reading Instruction and Reading Amount: A Comparison of Junior and Senior Secondary Students in Hong Kong. Journal of Research in Reading, 32(4), 366-382. 
Lau, S. (1997). Self-Concept Development: Is there a Concept of Self in Chinese Culture. In S. Lau (ed.), Growing up the Chinese Way: Chinese Child and Adolescent Development (pp. 327-373). Hong Kong: The Chinese University Press.

Lepper, M. R., Corpus, J. H., \& Iyengar, S. S. (2005). Intrinsic and Extrinsic Motivational Orientations in the Classroom: Age Difference and Academic Correlates. Journal of Educational Psychology, 97(2), 184-196.

Lin, D., Wong, K. K., \& McBride-Chang (2012). Reading Motivation and Reading Comprehension in Chinese and English among Bilingual Students. Reading and Writing, 25(3), 717-737.

Linnenbrink, E. A., \& Pintrich, P. R. (2003). The Role of Self-Efficacy Beliefs in Student Engagement and Learning in the Classroom. Reading \& Writing Quarterly, 19(2), 119-137.

Marinak, B., \& Gambrell, L. B. (2010). Reading Motivation: Exploring the Elementary Gender Gap. Literacy Research and instruction, 49(2), 129-141.

Mazzoni, S. A., Gambrell, L. B., \& Korkeamaki, R. (1999). A Cross-Cultural Perspective of Early Literacy Motivation. Journal of Reading Psychology, 20(3), 237-253.

Meece, J. K. (1994). The Role of Motivation In Self-Regulated Learning. In D. H. Schunk \& B. J. Zimmerman (Eds.), Self-Regulation of Learning and Performance: Issues and Educational Application (pp. 25-44). Hillsdale, NJ: Erlbaum.

Merisuo-Storm, T. (2006). Girls and Boys Like to Read and Write Different Texts. Scandinavian Journal of Educational Research, 50(2), 111-125.

Mokhtari, K., Reichard, C., \& Gardner, A. (2009). The Impact of Internet and Television Use on the Reading Habits and Practices of College Students. Journal of Adolescent \& Adults Literacy, 92(7), 609-619.

Mohamed, M., Rahman, R. A., Tin, L. C., Hashim, H., Maarof, H., Nasir, N. S. M., et al. (2012). Reading Behaviors of Students in Kolej Datin Seri Endon (KDSE). International Journal of Educational Management, 26(4), 381-390.

Mori, S. (2002). Redefining Motivation to Read in a Foreign Language. Reading in a Foreign Language, 14(2), 91-110.

Mounts, N. S., Valentiner, D. P., Anderson, K. L., \& Boswell, M. K. (2006). Shyness, Sociability, and Parental Support for the College Transition: Relation to Adolescents' Adjustment. Journal of Youth and Adolescence, 35(1), 68-77.

Mucherah, W., \& Yoder, A. (2008). Motivation for Reading and Middle School Students' Performance on Standardized Testing in Reading. Reading Psychology, 29(3), 214235.

Paul, J.A., Baker, H. M., \& Cochran, J. D. (2012). Effect of Online Social Networking on Student Academic Performance. Computers in Human Behavior, 28(6), 2117-2127.

Peregoy, S. F., \& Boyle, O. F. (2017). Reading, Writing and Learning in ESL: A Resources Book for Teaching K-12 English Learners. $7^{\text {th }}$ Edition. New York: Pearson.

Perna, L. W. (2010). Understanding the Working College Students. Academe, 96, $30-3$.

Pitcher, S. M., Albright, L. K., DeLaney, G. J., Walker, N. T., Seunarienesingh, K., Moggee, S., et al. (2007). Assessing Adolescents' Motivation to Read. Journal of Adolescent \& Adult Literacy, 50(5), 278-396.

Salili, F. (1995). Explaining Chinese Motivation and Achievement. In M. L. Maehr \& P. R. Pintrich (eds.), Advances in Motivation and Achievement: Culture, Motivation, and achievement (pp. 73-118). Greenwich, CT: JAI.

Salili,F., Chiu, C., \& Lai, S. (2001). The Influence of Culture and Context on Students' Motivational Orientation and Performance. In F. Salili, C. Chiu, \& Y. Hong (eds.), Student Motivation: The Culture and Context of learning (pp. 221-247). New York: Kluwer Academic. 
Vol. 9, No. 2 Huang \& Reynolds: Facts that Influence College Students'Reading...

Sanoff, A. P. (2006). What Professors and Teachers Think: A Perception Gap over Students' Preparation. The Chronicle of Higher Education, 52(27).

Schaffner, E., Schiefele, U., \& Ulferts, H. (2013). Reading amount as a Mediator of the Effects of Intrinsic and Extrinsic Reading Motivation on Reading Comprehension. Reading Research Quarterly, 48(4), 369-385.

Schiefele, U. (1991). Interest, Learning, and Motivation. Educational Psychologist, 26(34), 299-323.

Schiefele, U., Schaffner, E., Moller, J., \& Wigfield, A. (2012). Dimensions of Reading Motivation and their Relation to Reading Behavior and Competence. Reading Research Quarterly, 47(1), 427-463.

Schunk, D. H. (2003). Self-Efficacy for Reading and Writing Influence of Modeling, Goal Setting, and Self-Evaluation. Reading \& Writing Quarterly, 19(2), 159-172.

Schunk, D. H., \& Pajares, F. (2002). The Development of Academic Self-Efficacy. In L. Wigfield., \& J. S. Eccles (eds.). Development of Achievement Motivation (pp. 15-31). San Diego, CA: Academic Press.

Schunk, D. H., \& Zimmerman, B. J. (1997). Social Origins of Self-Regulatory Competence. Educational Psychologist, 32(4), 195-208.

Schutte, N. S., \& Malouff, J. M. (2004). University Students' Reading Preferences in Relation to the Big Five Personality Dimension. Reading Psychology, 25(4), 273195.

Shavelson, R. J., \& Bolus, R. (1982). Self-Concept: The Interplay of Theory and Methods. Journal of Educational Psychology, 74(1), 3-17.

Simpson, M. L., \& Rush, L. (2003). College Students' Beliefs, Strategy Employment, Transfer, and Academic Performance: An Examination across Three Academic Disciplines. Journal of College Reading and Learning, 33(2), 146-156.

Siskin, H. J. (Ed.) (2008). From Thought to Action: Exploring Beliefs and Outcomes in the Foreign Language Program. Boston: Thomson.

Starcher, K., \& Proffitt, D. (2011). Encouraging Students to Read: What Professors are (and aren't) Doing about it. International Journal of Teaching and Learning in Higher Education, 23(3), 396-407.

Stipek, D. (2002). Good Instruction in Motivating. In A. Wigfield \& J. S. Eccles (eds.), Development of Achievement Motivation (pp. 309-332). San Diego, CA: Academic Press.

Sweet, A. P. (1997). Teacher Perceptions of Student Motivation and Teacher Relation to Literacy Learning. In J. T. Guthrie., \& Wigfield, A. (eds.). Reading Engagement: Motivating Readers through Integrated Instruction (pp. 86-101). Newark, Delaware: International Reading Association.

The Institute for Higher Education Policy (February 2010). A Snapshot of African Americans in Higher Education. The Institute for Higher Education Policy.

Turner, J. C. (1995). The Influence of Classroom Contexts on Young Children's Motivation for Literacy. Reading Research Quarterly, 30(3), 410-441.

Turner, J. C. (1997). Starting Right: Strategies for Engaging Young Literacy Learners. In J. T. Guthrie., \& Wigfield, A. (eds.).Reading Engagement: Motivating Readers through Integrated Instruction (pp. 183-204). Newark, Delaware: International Reading Association.

Turner, J. C. (2001). Using Context to Enrich and Challenge our Understanding of Motivation Theory. In S. Volet, \& S. Jarvela (eds.), Motivation in Learning Contexts: Theory Advances and Methodological Implication (pp. 85-104). New York: Pergamon.

Wang, J. H., \& Guthrie, J. T. (2004). Modeling the Effects of Intrinsic Motivation, Extrinsic Motivation, and Amount of Reading, and Past Reading Achievement on 
Text Comprehension between U.S. and Chinese Students. Reading Research Quarterly, 39(2), 162-186.

Wentzel, K. R. (1997). Students Motivation in Middle School: The Role of Perceived Pedagogical Caring. Journal of Educational Psychology, 89(3), 411-419.

Wentzel, K. R. (1994). Relations of Social Goal Pursuit to Social Acceptance, Classroom Behavior, and Perceived Social Support. Journal of Educational Psychology, 86(2), 173-182.

Wentzel, K. R. (1996). Social and Academic Motivation in Middle School: Concurrent and Long-Term Relations to Academic Effort. Journal of Early Adolescence, 16(4), 390-406.

Wigfield, A. (1997). Children's Motivations for Reading and Reading Engagement. In J. T. Guthrie, \& Wigfield, A. (eds.). Reading Engagement: Motivating readers through Integrated Instruction (pp. 13-33). Newark, Delaware: International Reading Association.

Wigfield, A. (2000). Facilitating Children's Reading Motivation. In L. Baker., M. J. Dreher., \& J. Guthrie (Eds.). Engaging your Reader S: Promoting Achievement and Motivation (pp. 140-158). New York: The Guilford Press.

Wigfield, A., Eccles, J. S., Schiefele, U., Roeser, R., \& Davis-Kean, P. (2006). Development of Achievement Motivation. In W. Damon (Series ed.), \& N. Eisenberg (Volume ed.), Handbooks of Child Psychology (6 ${ }^{\text {th }}$ Edition, Volume 3, pp. 933-1002). New York: Wiley.

Wigfield, A., \& Eccles, J. (2002). Introduction. In L. Wigfield., \& J. S. Eccles (eds.), Development of Achievement Motivation (pp. 1-11). San Diego, CA: Academic Press.

Wigfield, A., \& Guthrie, J. T. (1997). Relations of Children's Motivation for Reading to the Amount and Breadth of their Reading. Journal of Educational Psychology, 89(3), 420-431.

Wigfield, A., Guthrie, J. T., Tonks., \& Perencevich, K. C. (2004). Children's Motivation for Reading: Domain Specificity and Instructional Influence. The Journal of Educational Research, 97(6), 299-309.

Wigfield, A., \& Wentzel, K. (2007). Introduction to Motivation at School: Interventions that Work. Journal of Educational Psychologist, 42(4), 191-196.

Wolters, G., \& Pintrich, P. (1998). Contextual Differences in Student Motivation and SelfRegulated Learning in Mathematics, English, and Social Studies Classroom. Instructional Science, 26(1-2), 27-47.

Yang, K. S. (1997). Theories and Research in Chinese Personality. An Indigenous Approach. In H. S. Kao, \& D. Sinha (eds.), Asian Perspective on Psychology (pp. 236-262). New Delhi: Sage Publications.

Yang, C. C. (2016). Social Media as More than a Peer Space: College Freshmen Encountering Parents on Facebook. Journal of Adolescent Research, 33, 1-28.

Yeung, A. S., Lau, S., \& Nie, Y. (2011). Primary and Secondary Students' Motivation in Learning English: Grade and Gender Differences. Contemporary Educational Psychology, 36(3), 246-256.

Yeung, A. S., \& Mclnerney, D. M. (2004). Students' School Motivation and Aspiration over High School Years. Educational Psychology, 25(5), 537-554. 


\section{Appendix A: Revised MRQ Survey}

\begin{tabular}{|c|c|}
\hline 1. & I always do well or enjoy any reading assignments. \\
\hline 2. & I believe I am a good reader. \\
\hline 3. & I learn and gain knowledge/information from reading. \\
\hline 4. & $\begin{array}{l}\text { In comparison to my other school subjects and assignments, I can do best at } \\
\text { reading. }\end{array}$ \\
\hline 5. & I frequently gain new vocabulary words or new concepts when I read. \\
\hline 6. & It is easy for me to get the meaning of the most complex sentences. \\
\hline 7. & $\begin{array}{l}\text { It is easy for me to use context clues or other strategies to analyze the text } \\
\text { structure. }\end{array}$ \\
\hline 8. & I can get the main theme(s) and comprehend well the text when I read. \\
\hline 9. & $\begin{array}{l}\text { If the instructor/professor discusses something interesting, I want to read more } \\
\text { about it. }\end{array}$ \\
\hline 10. & read about topics that interest me. \\
\hline 11. & about current things such as world news and popular books. \\
\hline 12. & $\mathrm{k}$ of time when I am reading about an interesting topic. \\
\hline 13. & Pictures, images, and stories often come to my mind when I read. \\
\hline 14. & $\begin{array}{l}\text { If a book is interesting, I do not care about the difficulty of the reading or the } \\
\text { length of the book. }\end{array}$ \\
\hline 15. & ading information, including online reading materials. \\
\hline 16. & $\begin{array}{l}\text { I like reading different types of books such as E-books and popular books for } \\
\text { adults. }\end{array}$ \\
\hline 17. & $\begin{array}{l}\text { I like hearing the professors say I perform well or making comments such as } \\
\text { "doing an excellent job." }\end{array}$ \\
\hline 18. & $\begin{array}{l}\text { I am pleased when someone recognizes my literacy skills and content knowledge } \\
\text { related to my major areas. }\end{array}$ \\
\hline 19. & Achieving a good grade is my motivating force for doing well in college. \\
\hline 20. & Receiving good grades is important to me. \\
\hline 21. & $\begin{array}{l}\text { Being more knowledgeable than anyone else and being recognized could } \\
\text { encourage me to a high quality of work and performance. }\end{array}$ \\
\hline 22. & $\begin{array}{l}\text { I'd rather read technological/scientific/mathematical books rather than a novel for } \\
\text { adults. }\end{array}$ \\
\hline 23. & accurate information than my friends. \\
\hline 24. & I like \\
\hline 25. & I often \\
\hline 26. & I like to spend time reading course assignments with my friends. \\
\hline 27. & I like to exchange or share books with my friends. \\
\hline 28. & I often share with my online friends or in person about what I am reading. \\
\hline 29. & I like to do my schoolwork with my friends. \\
\hline 30. & d books to my friends. \\
\hline 31. & ad d b \\
\hline 32. & $\begin{array}{l}\text { I do reading assignments and other projects well because I am expected to do } \\
\text { well. }\end{array}$ \\
\hline
\end{tabular}

